\title{
EJEM \\ Econ.J.Emerg.Mark.

\section{Determinants of capital expenditure spending in Malaysian palm oil industries: A dynamic panel data analysis}

\author{
Afza Asyura Mohd Hisham*, Zulkefly Abdul Karim, Norlin Khalid \\ Center of Sustainable and Inclusive Development (SID), Faculty of Economics and Management, Universiti \\ Kebangsaan Malaysia, Selangor, Malaysia \\ *Corresponding author: p88724@siswa.ukm.edu.my
}

\begin{tabular}{|c|c|}
\hline & bs \\
\hline & \multirow{6}{*}{$\begin{array}{l}\text { This study aims to investigate the determinants of capital expenditure } \\
\text { (capex) for Malaysian palm oil companies listed at Bursa Malaysia. The } \\
\text { study uses the dynamic panel data analysis (generalized method of } \\
\text { moment) estimation for the sample of } 40 \text { palm oil-oriented firms that } \\
\text { - spanning from year } 2000 \text { until } 2016 \text {. Findings/Originality: The } \\
\text { empirical findings revealed that, in the short run and the long run, the } \\
\text { capex spending is significantly affected by the cash flow, sale growth, and } \\
\text { world crude palm oil price. However, Average Q significantly influences } \\
\text { the capex decision in the long run only. Thus, the policy implication from } \\
\text { this study suggests that palm oil-oriented firms should take into account } \\
\text { the movement of world crude palm oil (CPO) price in designing their } \\
\text { capital expenditure strategy. In addition, proper planning for managing } \\
\text { firms' cash flow and sale growth are also important for expanding. } \\
\text { their capex in future. }\end{array}$} \\
\hline & \\
\hline Keyze & \\
\hline & \\
\hline sijicat & \\
\hline U1: & \\
\hline
\end{tabular}

\section{Introduction}

One of the most important aspects in every business is to evaluate the capital expenditure (capex) of the business because capex clearly gives an idea to maintain or increase the scope of operations and activities. Generally, capex is funds used by a company to acquire, upgrade, and maintain physical assets such as property, industrial buildings, or equipment. Capex is often used to undertake new projects or investments by the company. Thus, capex analysis is need an annually basis to generate additional profits in the future. Study by Pandey (1989) found that Indian companies have practiced a systematic capex management by controlling of capital expenditure using regular project reports. In the survey, six companies required quarterly reporting, four companies monthly, one company half-yearly and yet another company required continuous reporting. The evaluation reports include information on expenditure to date, stage of physical completion, approved and revised total cost. In facts, many factors may affect the propensity of investors to make capital expenditures within a specific sphere of economic activity which is often complex and difficult to quantify. These factors can be generally classified as macroeconomic and microeconomic factors. Using microeconomic level data allows us to consider the role of firmspecific variable, while macroeconomic factors are concerned with the economy as a whole.

In Malaysia, palm oil industry plays an important role in the economic development as well as enhancing the country's socioeconomic level. This has been proven by the contributions of Malaysian palm oil industry where in 2016, it is the fourth largest contributor to the national income, accounting for RM 63 billion of Malaysia's Gross National Income (GNI). Malaysia is the second largest producers of palm oil which are being consumed all over the world and has become a key economic growth driver in Malaysia. In year 2017, Malaysia was contributed about 35\% of 
palm oil global production, Indonesia (54\%), and the remaining $17 \%$ consists of Thailand (4\%), Colombia (2\%), Nigeria (1\%), and other countries (10\%). Palm oil will continue to be the main oil produced due to its highest productivity and as such the main oil to be consumed in the future due to its price relatively cheaper and comparatively a healthy oil. Highly demand of palm oil required palm oil industry to increase their productivity. Therefore, in order to maintain the contribution of the palm oil industry to the Malaysian economy, study relating to the determinants of the investment decision is important, not only to the palm oil companies for their business planning but also to the government agency for designing a new policy that can promote more investment on the palm oil companies. This is due to the fact that more fixed investment generally leads to improve palm oil productivity, maintaining the sustainability of the palm oil production, and also can continually contribute to the economy in the long run.

In recent years, there are many new technology of harvester machines has stimulated in palm oil industry to improve productivity and make easier some of the tasks, which are manually performed (Nur Syazwani, Baba, \& Norani, 2014). This is supported by Jelani et al. (2008) who stated that labour productivity can be increased by several factors such as adopting new technology, improving cultural practices, mechanized field operations and improving the quality of the workforce. Mat and Razak (2011) argued that technology plays a very significant role and needs to be explored extensively in order to develop strategies for sustainable growth in an increasingly competitive industry. In the meantime, Malaysia is also facing an environmentally-polluting because of the huge amounts of waste, including kernels and husks from pressed fruits, discarded branches and wastewater known as Palm Oil Mill Effluent (POME). Therefore, given this current development in the palm oil industry, a proper plan of capex investment in research and development $(\mathrm{R} \& \mathrm{D})$ is very crucial for upgrading the harvester machines with adopting newly innovated technologies as well as new the creation of technology that can avoid negative externalities of palm-oil production. Therefore, understanding the main factors that affects the investment decision of palm oil-oriented firms is important for firms in planning and strategizes their business plan in future.

In order to expand the business, the palm oil-oriented companies need to have a proper plan on their capex strategies in maximizing their productivity and profit in future. Therefore, understanding the main factors that affect the investment decision is crucial to the managers in order to have an accurate assessment of their business plan. Most previous articles show similar findings in which capex spending appears to depend on sales and cash flows in common investment equations. The cash flow emphasizes the importance of internal funds, in which that signal the firm to have enough funds for new investments and also indicate the profitability of past investment (Kopcke, 1993). A greater cash flow not only permits an expansion of capital budgets, it also reflects a greater return on assets, which, in turn, may foster the demand for capital by increasing expected yields. Meanwhile, if sales are taken as the factor that influences the capex investment, the stock of capital can be expected to change with changes in sales and net investment may be taken as a distributed lag function of current and past changes in sales. Other factor influencing the expected capex spending may be captured by uncertainty in the movement of CPO price, in which an increase in price can trigger a positive effect on firm-level investment spending viability and the economic attractiveness of palm oil production. CPO price is a key driver of yields and share price. The movement in world CPO prices would directly impact the firm profitability. An inexplicable change in international trade can result in volatile CPO price but more importantly, a decline in CPO price could also occur because of weak Ringgit Malaysia. Logically, palm oil industry stands to benefit from the current issue of weaker ringgit, given the fact that palm oil is an export-oriented commodity using the US dollar or other foreign currencies, while the planters' cost of production is ringgit-denominated. Thus, domestic and world CPO price is employed in this study to evaluate the effect of industry pricing of CPO to capex performance. In this case, the 
investor should consider the market value of share to measure investment opportunities as well. Tobin's Q model highlights the correspondence between the value of corporations in financial markets and their demand for new capital. The performance of plantation stocks in relation to CPO prices is dictated by the productivity factor, where stronger or weaker the expected yields have led to higher or lower share price sensitivity to CPO prices. Overall, all those factors above will affect business profitability when those companies are not able to manage their capex spending and sub-standard field management.

The paper aims to explore the determinant of capital expenditure (capex) on Malaysian palm oil industry. This analysis is motivated by the predictions of a simple two-period model of firm investment that is similar to the models developed by Karim (2012) and Ismail, Ibrahim, Yusoff, and Zainal, (2010) for the Malaysian experienced. Karim (2012) has used a neoclassical demand for the capital framework in investigating the determinants of firm-level investment spending, whereas Ismail et al. (2010) used the Q model in which requires market value of a share to measure the average Q. The palm oil industry has been choosing as a sample because it's the most important sub-sector in the agricultural sector. Thus, the world CPO price is expected to play a significant role in affecting firm-level investment expenditure in the long run and short run respectively due to the fact that CPO prices are externally determined by world markets.

This paper contributes to the policy makers and the existing literature in following ways. First, to policy makers, based on Third National Agricultural Policy (1998-2010), the main goal of the agriculture sector of a developing country like Malaysia is to ensure that Malaysia's position in the world's oils and fats market is enhanced and its competitive edge maintained. Thus, this study has provided the idea to the stakeholder or industry players in palm oil industry to consider their capex strategies in generating additional profits in the future. For example, some firms in palm oiloriented industry need more capital intensive than labour intensive in their production level. Since the capital-intensive technology need more allocation in capex, especially to acquire a new machines and adopting newly innovated technologies, therefore understanding the determinants of their capex in necessary for the firms for their business and financial management plan. Second, to the existing literature this present study has extended the previous literature by focusing on the palm oil related companies using recent dataset and latest econometric methodology. In fact, using data set for palm oil related companies may shed some light for further understanding of their investment behaviour. This study also contributes to the existing literature using the augmented cash-flow investment model by controlling some variables in modelling the determinants of capex for palm oil related firms.

There are four competing investment models in explaining the behaviour of firm-level investment spending namely financial accelerator, neoclassical, cash flow and Tobin's Q models. Each model represents the way how the business conditions may influence the demand for capital. The financial accelerator model compares the recent trend in sales or output to existing productive capacity in order to estimate investors' demands for new capital goods. The neoclassical model essentially extends the accelerator model by permitting the correspondence between output and capital to vary with the cost of capital, which includes corporate income taxes and the relative price of investment goods. The cash flow model emphasizes the importance of internal funds, which both fund new investments and indicate the profitability of past investments. Finally, the Tobin's q model highlights the correspondence between the value of corporations in financial markets and their demand for new capital.

Some of studies investigated the firm level investment by using Tobin's-q baseline model. Sauaia (2002) for instance concluded Tobin's-q as incorporates to the past events, future tendencies (market value of the shares) including the expectations of success in the implementation of new projects. Another study argued that the relationship between the $\mathrm{q}$ ratio and future operating performance for a sample of publicly traded US firms shows that firms with higher q ratios 
experience superior operating performance in the long run (Singhal, Fu, \& Parkash, 2016). In the measurement perspective, Agung (2000) found that the firm investment spending in Indonesia is sensitive to future expected profit represented by average Q. Contradict with Gugler, Dennis, and Yurtoglu (2000), they say more relevant for investment decisions using the marginal return on capital. Marginal q has been estimated to identify the existence of cash constraints and managerial discretion and as a separate explanatory variable.

All those basic models take no explicit account of the companies' debt burdens, their size, the rate at which they are growing, or their lines of business. Bala, Darry, and Matthew (2005) in contrast focused on determinants affecting performance in Malaysia palm oil industry. The findings suggest that size is negatively related to performance while privately owned plantation companies are more profitably managed. Meanwhile, Subrahmanyam, Chhachhi, and Brown (2013) argued that a smaller firm with a higher market to book and lower institutional ownership to have higher capital expenditure. In contrast, a recent study by Norhidayu, Nur Syazwani, Radzil, Amin, and Balu (2017) has examined the performance of the Malaysian palm oil milling sector's productivity by using Cobb-Douglas (C-D) production function and found that CPO production was significantly and positively related to capital, labour and the utilization rate.

In Malaysia context, the previous study for example, Ismail et al. (2010), Karim (2012), and Karim and Azman-Saini (2013) have examined the determinants of firm-level investment without focusing on the palm-oil oriented firms. Ismail et al. (2010) argued that the present of financial constraint in the market, in which indicate that firms are unable to access the external financing due to the present of asymmetric information problem between firm and its financier. This study also rejects the neoclassical theory and concludes that the investment is much affected by fluctuations in their cash flows. However, Karim (2012) used the neoclassical model in examining the role of monetary policy through interest rate and broad credit channels upon the firms' investment spending. The main finding revealed that, in the long run, the firm investment of the consumer products and services sectors are significantly affected by the interest rate and broad credit channels. However, the firm investment in the industrial products and property sectors has only been significantly affected by interest rates and broad credit channel, respectively. Thus, the monetary authority has to consider the microeconomic aspects of the firm in formulating their monetary policy. Karim and Azman-Saini (2013) using a dynamic neoclassical investment model reveal that the effects of monetary policy channels on firm investment is heterogeneous, such that small firms (i.e credit constrained firms) are more responsive to monetary tightening when compared to large firms (i.e less constrained firms).

To the best of authors' knowledge, there is no empirical study has examined the determinant of capex in the palm oil industry specifically. Therefore, based on this backdrop, this present study makes a novel contribution to the existing literature by exploring the relevance of the movement of palm oil price upon the firm-investment (capex) in oil palm-oriented industry. Thus, for the estimation model, two types of prices that is Malaysian crude palm oil price (MP) and world crude palm oil price (WP) will be used to representing the role of palm oil prices on capex.

\section{Methods}

The data set has been collected from Thompson Datastream. This study uses unbalanced annual firm-level data spanning from 2000 up to 2016 (17 years) for the sample of 40 plantation oriented firms in which listed at the Bursa Malaysia's Main Board. Most of the firms have been listed continuously since 2000, but few firms are listed in the main board at some later point. In addition, the firms were selected that were consecutively present in the sample for at least five years in order to have sufficient number of lags as an explanatory variable. This is important to avoid data reduction due to the data transformation process and for adoption of lagged values in the model estimations (for example, in this study, the maximum lag order is two for all explanatory variables). 
The variable used in this study are investment $(I)$, capital $(K)$, average $Q(Q)$, cash flow $(C F)$, sales $(Y)$ and crude palm oil price $(C P O)$. Investment is the current period investment of time $t$ and equal to the purchase of property, plant and equipment. In this study, capital expenditure is used as a proxy of investment. For example, Bhagat, Moyen, and Suh (2005), Ismail et al. (2010) and Karim (2012) used capital expenditure as the proxy of investment. The second variable is Capital. Capital is the net firm fixed assets which exclude depreciation at the beginning of period $t$. It includes property, plant and equipment. The third variable is Cash Flow, defined as operating income after tax earning plus depreciation which has calculated at the beginning of period $t$. The depreciation includes total depreciation, amortization and depletion. This variable has used as a measurement for the degree of market imperfections caused by financial constraint. The fourth variable is sales. Sales refers to the percent of sales growth or revenue that has been calculated by subtracting current year's total sales from the previous year's total sales. Then, divide the result with the previous year's total sales and multiply the result with 100 to get the percentage increase or decrease in sales. And the last variable is average Q. the fifth variable is average Q, average Q is the beginning of period $t$. Tobin's q ratio is extensively used in the financial literature as a proxy for future investment opportunities. It is measured by dividing book value of total debt and market capitalization by firm total assets. The market capitalization is defined as common shares outstanding multiplied by their respective market prices. This definition of Q was used in Koo and Maeng (2005). The last variable is crude palm oil price. The world and domestic CPO price have been used at the beginning of the period t. The world's CPO price data was collected from Federal Reserve Economic Data in US dollar (USD), while the domestic's CPO price was collected from Malaysian Palm Oil Board (MPOB) in Malaysian Ringgit (RM).

Cash flow investment model has been used as baseline model in investigating the determinant of capex. The cash flow theory emphasizes the importance of internal funds in financing the new investments and also indicates the profitability of past investments. Fazzari, Hubbard, and Petersen (1988) argue that cash flow represents the availability of internal funds and can capture firm's financial position. The expected sign is positive because an increase in cash flow will increase firm investment spending. This finding is consistent with Karim (2012) who argued that a small firm is heavily reliant on internal funds as a cheaper source of funds and has some difficulties in accessing external financing.

The basic of investment equation using cash flow model can be written as follows:

$I_{t}=a+\sum_{i=0}^{n} b_{i}\left(\frac{F}{C}\right)_{t-i}$

Where $I$ is the real investment, $F$ represents cash flow and $C$ is price index for capital goods. Besides cash flow, the role of sales growth has been taken into account and also consistent with the financial accelerator theory, in which postulates that a positive relationship between sales and investment. According to financial accelerator theory, an increase in sales fosters the demand for plant and equipment investment. Thus, by considering the cash flow and sales, the capex model in ARDL $(2,2)$ estimation can be expressed as follows:

$$
\begin{aligned}
& \frac{I_{i t}}{K_{i, t-1}}=a_{1}\left(\frac{I_{i, t-1}}{K_{i, t-2}}\right)+a_{2}\left(\frac{I_{i, t-2}}{K_{i, t-3}}\right)+\theta_{0} \Delta \log \text { Sale }_{i, t}+\theta_{1} \Delta \log \text { Sale }_{i, t-1}+\theta_{2} \Delta \log \text { Sale }_{i, t-2}+ \\
& \sigma_{0}\left(\frac{C_{i, t}}{K_{i, t-1}}\right)+\sigma_{1}\left(\frac{C_{i, t-1}}{K_{i, t-2}}\right)+\sigma_{2}\left(\frac{C_{i, t-2}}{K_{i, t-3}}\right)+\mu_{i}+\pi_{t}+v_{i t}
\end{aligned}
$$

However, model in equation (2) does not consider the role of market value of share (Tobin Q) to measure of investment opportunities, and also the movement of palm oil price. Then, equation (2) is modified to include Tobin's Q model to highlight the correspondence between the value of corporations in financial markets and their demand for new capital. Average Q is used to measure the share price and control for investment opportunities so that cash flows' effect is limited to its 
role as a source of liquidity. It also can measure the cost of external finance for firms (Gugler et al., 2000). In addition, the price factor is also employed in the model to evaluate the movement of $\mathrm{CPO}$ price to firm-level investment spending. Two types of CPO price (PP) namely the Malaysian crude palm oil price (MP) and world crude palm oil price (WP) will be considered separately in the estimation model. Thus, the final specification model of the determinants of capex is follows:

$$
\begin{aligned}
& \frac{\mathrm{I}_{\mathrm{it}}}{\mathrm{K}_{\mathrm{i}, \mathrm{t}-1}}=\mathrm{a}_{1}\left(\frac{\mathrm{I}_{\mathrm{i}, \mathrm{t}-1}}{\mathrm{~K}_{\mathrm{i}, \mathrm{t}-2}}\right)+\mathrm{a}_{2}\left(\frac{\mathrm{I}_{\mathrm{i}, \mathrm{t}-2}}{\mathrm{~K}_{\mathrm{i}, \mathrm{t}-3}}\right)+\theta_{0} \Delta \log \text { Sale }_{\mathrm{i}, \mathrm{t}}+\theta_{1} \Delta \log \text { Sale }_{\mathrm{i}, \mathrm{t}-1}+\theta_{2} \Delta \log \text { Sale }_{\mathrm{i}, \mathrm{t}-2}+ \\
& \sigma_{0}\left(\frac{\mathrm{CF}_{\mathrm{i}, \mathrm{t}}}{\mathrm{K}_{\mathrm{i}, \mathrm{t}-1}}\right)+\sigma_{1}\left(\frac{\mathrm{CF}_{\mathrm{i}, \mathrm{t}-1}}{\mathrm{~K}_{\mathrm{i}, \mathrm{t}-2}}\right)+\sigma_{2}\left(\frac{\mathrm{CF}_{\mathrm{i}, \mathrm{t}-2}}{\mathrm{~K}_{\mathrm{i}, \mathrm{t}-3}}\right)+\beta_{0} \mathrm{Q}_{\mathrm{i}, \mathrm{t}}+\beta_{1} \mathrm{Q}_{\mathrm{i}, \mathrm{t}-1}+\beta_{2} \mathrm{Q}_{\mathrm{i}, \mathrm{t}-2}+\varphi_{0} \log \mathrm{PP}_{\mathrm{i}, \mathrm{t}}+ \\
& \varphi_{1} \log \mathrm{PP} \mathrm{i}_{\mathrm{i}, \mathrm{t}-1}+\varphi_{2} \log \mathrm{PP} \mathrm{P}_{\mathrm{i}, \mathrm{t}-2}+\mu_{\mathrm{i}}+\pi_{\mathrm{t}}+\mathrm{v}_{\mathrm{it}}
\end{aligned}
$$

Where, $\mu_{\mathrm{i}}+\pi_{\mathrm{t}}+\nu_{\mathrm{it}}=\varepsilon_{\mathrm{it}}$. The error term $\left(\varepsilon_{\mathrm{it}}\right)$ is assumed to follow two-way error components disturbances which is the unobservable firm-specific effect $\left(\mu_{\mathrm{i}}\right)$ and unobservable time-specific effects $\left(\pi_{\mathrm{t}}\right) \cdot v_{i t} \sim \ddot{i} d\left(0, \sigma_{v}^{2}\right)$ it is the remainder stochastic disturbance term, which is assumed to be independent and identically distributed with mean zero and constant variance. The dependent variable is the firm level investment spending measured by the ratio of capital expenditure to lagged capital stock $\left(\mathrm{I}_{\mathrm{it}} / \mathrm{K}_{\mathrm{i}, \mathrm{t}-1}\right)$. The independent variables are the cash flow to lagged capital stock ratio $\left(\mathrm{CF}_{\mathrm{i}, \mathrm{t}} / \mathrm{K}_{\mathrm{i}, \mathrm{t}-1}\right)$, sales growth $(\Delta \log$ Sale $)$, average $\left(\mathrm{Q}_{\mathrm{i}, \mathrm{t}}\right)$ and $\mathrm{CPO}$ price $\left(\log \mathrm{PP}_{\mathrm{i}, \mathrm{t}}\right)$.

The inclusion of the lagged dependent variables in the capex model in equation (3) implies that there is correlation between the regressors and the error term since the lag of the investment ratio $\left(I_{i, t-1} / K_{i,-2-2}\right)$ depends on $\varepsilon_{i, t-1}$ which is a function of the firm-specific effect $\left(\mu_{i}\right)$ and time-specific effect $\left(\pi_{t}\right)$. Therefore, due to this correlation, the dynamic panel data estimation in equation (3) suffers from Nickell (1981) bias, which disappears only if $\mathrm{T}$ is sufficiently large or approaches infinity. Arellano and Bond (1991), Arellano and Bover (1995), and recently extended by Blundell and Bond (1998) have proposed generalized method of moments (GMM) estimators in order to deal the endogeneity problem (the correlation between the lagged dependent variable and the error term).

Generalized Moments (GMM) method has advantages in estimating the panel data, as it is able to overcome unobserved individual effect, endogeneity of explanatory variables and the use of lagged dependent variables by applying the full set of moment conditions without ignoring the difference structure on the residual disturbances (Baltagi, 2005). There are two types of GMM. The first GMM is the difference GMM proposed by Arellano and Bond (1991), has been widely used in the most recent empirical literature concerning the role of firm-level investment. Arellano and Bover (1995) developed a new GMM technique to incorporate the Hausman and Taylor (1981) in order to obtain efficient results in dynamic panel data. Blundell and Bond (1998) used the orthogonality conditions given in Arellano and Bover (1995) and introduced the system GMM to overcome the weak instrument of the difference GMM.

Therefore, there are three specifications tests as suggested by Arellano and Bond (1991), Arellano and Bover (1995), and Blundell and Bond (1998). First, the Hansen test of overidentifying restrictions, which tests the overall validity of the instruments by analysing the sample analogue of the moments conditions used in the estimation process. If the moment condition holds, then the instrument is valid and the model has been correctly specified. Second, it is important to test that there is no serial correlation among the transformed error term. Third, to test the validity of extra moment's conditions on the system GMM, the difference in Hansen test is used. This test measures the difference between the Hansen statistic generated from the system GMM and the difference GMM. Failure to reject the three null hypotheses gives support to the estimated model.

However, this study has used system GMM estimation. Instrument for orthogonal deviation equation are lags 2 to all available lags for endogenous variables (lagged dependent 
variable), lags 2 to all available lags for all pre-determined variables (cash flow to capital stock ratio, sales growth and average $\mathrm{q}$ ) and all lags for strictly exogenous variable (CPO price) for Panel A and Panel B. The estimation also collapses the instruments matrix as proposed by Calderon, Chong, and Loayza (2002) and Roodman (2009). The short-run effects can be tested by checking the signs and significance of the sum of coefficients for each variable. For robustness checking, two-step estimation in the system GMM was also considered. From Equation (3), the long-run effect of the explanatory variables are defined as the sum of the coefficients on the explanatory variable divided by one minus the sum of the coefficient on the lagged dependent variable. For example, the long run elasticity of investment with respect to cash flow to capital stock ration is $\sigma=\left(\frac{\sigma_{0+} \sigma_{1+} \sigma_{2}}{1-\alpha_{1}-\alpha_{2}}\right)$; the long run elasticity of investment with respect to sales growth is given as $\theta=\left(\frac{\theta_{0+} \theta_{1+} \theta_{2}}{1-\alpha_{1}-\alpha_{2}}\right)$; the long run elasticity of investment with respect to average $Q$ is $\beta=\left(\frac{\beta_{0}+\beta_{1+} \beta_{2}}{1-\alpha_{1}-\alpha_{2}}\right)$; and the long run elasticity of investment with respect to crude palm oil price is $\varphi=\left(\frac{\varphi_{0+\varphi_{1+}} \varphi_{2}}{1-\alpha_{1}-\alpha_{2}}\right)$. This is call delta method estimated by using Nlcom Syntax in STATA.

\section{Result and Discussion}

First analysis is short run elasticity analysis. Table 2 reports the estimation results of the capex model on Malaysian palm oil industry which divided into Panel A and Panel B. Panel A uses domestic CPO price, while Panel B uses world CPO price. As can be seen in Table 1, capex in the palm oil industry is statistically significant affected by the cash flow to capital stock ratio. The results show a 1 percent increase in cash flow to capital stock ratio will lead to an increase in investment spending by 0.036 percent. This finding is consistent with Karim (2012) finding in which showed positive sign which implies the larger cash flow would lead to more spending in their capital expenditure.

The total coefficient of sales growth shows a lower impact compared to cash flow in influencing firms' investment in the Malaysian palm oil industry. For example, investment increases by 0.001 percent in response to a 1 percent increase in sales growth. The inclusion of this variable is consistent with the financial accelerator theory, which postulates that there is a positive relationship between sales and investment. For example, an increase in sales growth is associated with more capital expenditure and increases the rate of investment. Besides, the average Q is not responsive to capex in the short run. The poor performance of Tobin's Q to explain variation in corporate investment has been discussed by some previous researchers. For example, Joseph and $\mathrm{Wu}$ (2000) attribute this poor performance to measurement error in Q as a classic error in explanatory variables problem. Q effects on capex spending come with some time lag, depending on the average depreciation period and time to realization of related top-line effects. If $Q$ is measured with error, its explanatory power will be reduced and its coefficient will be biased toward zero.

In terms of price perspective, only world CPO price is significant in influencing the investment spending with the negative coefficient. Increase in world palm oil price will lead to decrease the spending in capex in the short run. Naturally, increase in market price and stronger demand for palm oil will lead the investor to invest more in the future to upgrade their physical assets.

The serial correlation test shows that the System GMM estimations are not serially correlated at the second order or AR (2). In fact, the Hansen test shows that the system GMM estimation is well specified and the instruments employed are valid because the p-value is greater than 0.1 . The validity of additional moment conditions such as the difference in Hansen tests are also statistically insignificant in all models, but not reported in order to save space. 
Table 1. The determinant of CAPEX in palm oil industry: System GMM estimation - two step estimation

\begin{tabular}{|c|c|c|c|c|c|c|c|}
\hline \multirow{2}{*}{ Independent Variable } & \multicolumn{3}{|c|}{$\begin{array}{c}\text { Panel A - Malaysia Palm Oil } \\
\text { Price }\end{array}$} & \multirow{2}{*}{ Independent Variable } & \multicolumn{3}{|c|}{$\begin{array}{c}\text { Panel B - World Palm Oil } \\
\text { Price }\end{array}$} \\
\hline & Coef. & $\begin{array}{l}\text { Corrected } \\
\text { SE }\end{array}$ & P-value & & Coef. & $\begin{array}{l}\text { Corrected } \\
\text { SE }\end{array}$ & P-value \\
\hline$\left(\mathrm{I}_{\mathrm{t}-1} / \mathrm{K}_{\mathrm{t}-2}\right)$ & -0.006 & 0.165 & 0.970 & $\left(\mathrm{I}_{\mathrm{t}-1} / \mathrm{K}_{\mathrm{t}-2}\right)$ & -0.016 & 0.154 & 0.916 \\
\hline$\left(\mathrm{I}_{\mathrm{t}-2} / \mathrm{K}_{\mathrm{t}-3}\right)$ & 0.366 & 0.100 & 0.000 & $\left(\mathrm{I}_{\mathrm{t}-2} / \mathrm{K}_{\mathrm{t}-3}\right)$ & 0.379 & 0.114 & 0.001 \\
\hline$\sum\left(\mathrm{I}_{\mathrm{i}, \mathrm{t}-\mathrm{n}} / \mathrm{K}_{\mathrm{i}, \mathrm{t}-\mathrm{n}-1}\right)$ & 0.360 & 0.265 & $0.001 * *$ & $\sum\left(\mathrm{I}_{\mathrm{i}, \mathrm{t}-\mathrm{n}} / \mathrm{K}_{\mathrm{i}, \mathrm{t}-\mathrm{n}-1}\right)$ & 0.363 & 0.268 & $0.004 * *$ \\
\hline$\left(\mathrm{CF}_{\mathrm{i}, \mathrm{t}} / \mathrm{K}_{\mathrm{i}, \mathrm{t}-\mathrm{-}}\right)$ & 0.013 & 0.009 & 0.133 & $\left(\mathrm{CF}_{\mathrm{i}, \mathrm{t}} / \mathrm{K}_{\mathrm{i}, \mathrm{t}-1}\right)$ & 0.012 & 0.009 & 0.215 \\
\hline$\left(\mathrm{CF}_{\mathrm{i}, \mathrm{t}-1} / \mathrm{K}_{\mathrm{i}, \mathrm{t}-2}\right)$ & 0.014 & 0.008 & 0.092 & $\left(\mathrm{CF}_{\mathrm{i}, \mathrm{t}-1} / \mathrm{K}_{\mathrm{i}, \mathrm{t}-2}\right)$ & 0.015 & 0.008 & 0.058 \\
\hline$\left(\mathrm{CF}_{\mathrm{i}, \mathrm{t}-2} / \mathrm{K}_{\mathrm{i}, \mathrm{t}-3}\right)$ & 0.009 & 0.004 & 0.050 & $\left(\mathrm{CF}_{\mathrm{i}, \mathrm{t}-2} / \mathrm{K}_{\mathrm{i}, \mathrm{t}-3}\right)$ & 0.009 & 0.006 & 0.119 \\
\hline$\sum\left(\mathrm{CF}_{\mathrm{i}, \mathrm{t}-\mathrm{n}} / \mathrm{K}_{\mathrm{i}, \mathrm{t}-\mathrm{n}-\mathrm{1}}\right)$ & 0.036 & 0.021 & $0.000^{* *}$ & $\sum\left(\mathrm{CF}_{\mathrm{i}, \mathrm{t}-\mathrm{n}} / \mathrm{K}_{\mathrm{i}, \mathrm{t}-\mathrm{n}-1}\right)$ & 0.036 & 0.023 & $0.000^{* *}$ \\
\hline$\Delta \log$ Sale $_{\mathrm{i}, \mathrm{t}}$ & 0.001 & 0.000 & 0.093 & $\Delta \log$ Sale $_{\mathrm{i}, \mathrm{t}}$ & 0.001 & 0.001 & 0.091 \\
\hline$\Delta \log$ Sale $_{\mathrm{i}, \mathrm{t}-1}$ & -0.000 & 0.000 & 0.873 & $\Delta \log$ Sale $_{\mathrm{i}, \mathrm{t}-1}$ & -0.000 & 0.000 & 0.826 \\
\hline$\Delta \log$ Sale $_{\mathrm{i},-2}$ & -0.000 & 0.000 & 0.000 & $\Delta \log$ Sale $_{\mathrm{i}, \mathrm{t}-2}$ & -0.000 & 0.000 & 0.017 \\
\hline$\sum \Delta \log$ Sale $_{\mathrm{i}, \mathrm{t}-\mathrm{n}}$ & 0.001 & 0.000 & $0.000^{* *}$ & $\sum \Delta \log$ Sale $_{\mathrm{i}, \mathrm{t}-\mathrm{n}}$ & 0.001 & 0.001 & $0.000 * *$ \\
\hline$\overline{\mathrm{Q}}_{\mathrm{i}, \mathrm{t}}$ & -0.118 & 0.064 & 0.065 & $\overline{\mathrm{Q}}_{\mathrm{i}, \mathrm{t}}$ & -0.050 & 0.075 & 0.509 \\
\hline $\mathrm{Q}_{\mathrm{i}, \mathrm{t}-1}$ & 0.173 & 0.111 & 0.118 & $\mathrm{Q}_{\mathrm{i}, \mathrm{t}-1}$ & 0.090 & 0.170 & 0.596 \\
\hline $\mathrm{Q}_{\mathrm{i}, \mathrm{t}-2}$ & 0.011 & 0.051 & 0.827 & $\mathrm{Q}_{\mathrm{i}, \mathrm{t}-2}$ & 0.005 & 0.049 & 0.926 \\
\hline$\sum \mathrm{Q}_{\mathrm{i}, \mathrm{t}-\mathrm{n}}$ & 0.066 & 0.226 & 0.170 & $\sum \mathrm{Q}_{\mathrm{i}, \mathrm{t}-\mathrm{n}}$ & 0.045 & 0.294 & 0.717 \\
\hline$\overline{\log } \mathrm{MP}_{\mathrm{i}, \mathrm{t}}$ & 0.039 & 0.083 & 0.635 & $\overline{\log } \mathrm{WP}_{\mathrm{i}, \mathrm{t}}$ & -0.492 & 0.249 & 0.049 \\
\hline $\log \mathrm{MP}_{\mathrm{i}, \mathrm{t}-1}$ & -0.298 & 0.156 & 0.056 & $\log \mathrm{WP}_{\mathrm{i}, \mathrm{t}-1}$ & 0.614 & 0.485 & 0.206 \\
\hline $\log \mathrm{MP}_{\mathrm{i}, \mathrm{t}-2}$ & 0.138 & 0.220 & 0.529 & $\log \mathrm{WP}_{\mathrm{i}, \mathrm{t}-2}$ & -0.205 & 0.160 & 0.200 \\
\hline$\sum \log M P_{i, t-n}$ & -0.121 & 0.459 & 0.281 & $\sum \log \mathrm{WP}_{\mathrm{i}, \mathrm{t}-\mathrm{n}}$ & -0.083 & 0.894 & $0.036^{* *}$ \\
\hline No. of observations & 497 & & & No. of observations & 497 & & \\
\hline No. of group & 40 & & & No. of group & 40 & & \\
\hline No. of instruments & 40 & & & No. of instruments & 40 & & \\
\hline Average per group & 12.43 & & & Average per group & 12.43 & & \\
\hline $\operatorname{AR}(2)-p$-value & 0.202 & & & $\mathrm{AR}(2)-\mathrm{p}$-value & 0.176 & & \\
\hline Hansen Test - p-value & 0.161 & & & Hansen Test $-\mathrm{p}$-value & 0.174 & & \\
\hline \multicolumn{8}{|c|}{$\begin{array}{l}\text { Notes: Significant at: } * 5 \text { and } * * 1 \text { percent significance levels; the p-value of the total coefficient was tested by using Wald statistic; } \\
\text { the dependent variable is the firm-level investment spending measured by the ratio of capital expenditure to lagged capital stock } \\
\left(\left(\mathrm{I}_{\mathrm{t}-1} / \mathrm{K}_{\mathrm{t}-2)}\right) \text {; the independent variables are the cash flow to lagged capital stock ratio }\left(\mathrm{CF}_{\mathrm{i}, \mathrm{t}} / \mathrm{K}_{\mathrm{i}, \mathrm{t}-1}\right) \text {, sales growth }(\Delta \log \text { Sale } \mathrm{i}, \mathrm{t}, \mathrm{and}\right. \\
\text { average } \mathrm{q}\left(\mathrm{Q}_{\mathrm{i}, \mathrm{t}} \text {; } \mathrm{AR}(2)=\text { second order autoregressive; all p-value of the difference in Hansen tests of exogeneity of instruments }\right. \\
\text { subsets have also been rejected at least at } 10 \text { percent significant level, but not reported here; the full results are available upon } \\
\text { request; Instrument for orthogonal deviation equation; Lags } 2 \text { to all available lags for endogenous variables (lagged dependent } \\
\text { variable), lags } 2 \text { to all available lags for all pre-determined variables (cash flow to capital stock ratio, sales growth and average } \mathrm{q}) \\
\text { and all lags for strictly exogenous variable (palm oil price) for Panel A and Panel B; the estimation also collapses the instruments } \\
\text { matrix as proposed by Calderon et al. (2002) and Roodman (2009). }\end{array}$} \\
\hline
\end{tabular}

Table 2. Long run coefficient of cash flow, sales growth, average q, Malaysia palm oil price and World palm oil price - by palm oil industry.

\begin{tabular}{lcll}
\hline Panel A - Malaysia Palm Oil Price & \multicolumn{2}{l}{ Panel B - World Palm Oil Price } \\
\hline Cash Flow & $0.407(0.212)^{*}$ & Cash Flow & $0.431(0.198)^{* *}$ \\
Sales Growth & $0.373(0.211)^{*}$ & Sales Growth & $0.396(0.199)^{* *}$ \\
Average q & $0.438(0.211)^{* *}$ & Average q & $0.440(0.223)^{* *}$ \\
Malaysia Palm Oil Price & $0.252(0.165)$ & World Palm Oil Price & $0.312(0.145)^{* *}$ \\
\hline
\end{tabular}

Notes: Significant at: $* 10$ and $* * 5$ percent significance levels; number in parenthesis is standard error computed by delta method (the delta method is estimated by using nlcom syntax in Stata); the long-run effects of the explanatory variables are defined as the sum of the coefficients on the explanatory variable divided by one minus the sum of the coefficient on the lagged dependent variable.

The further estimation is long rung elasticity analysis. Table 2 summarizes the long run elasticity of palm oil firm investment with respect to cash flow, Tobin q, sales, and the movement of palm oil prices. As can be seen from Table 2 (Panel A and Panel B), Tobin's q, cash flow and sales growth are positive and statistically significant for influencing investment in the long run. This 
finding is also in line with Ismail et al. (2010) who argued that firm investment spending is sensitive to future expected profit represented by average Q. Besides, Gugler et al. (2000) conclude many managers of firms with relatively high share prices and cash flows appear to take advantage of the discretion they have to expand their companies beyond the point that is optimal from the point of view of their shareholders.

Meanwhile, only world palm oil price has a positive relationship with investment in the long run. Increase in price will lead to an increase in investment spending. Logically, palm oil industry stands to benefit from the current issue of weaker ringgit, given the fact that palm oil is an exportoriented commodity using the US dollar or other foreign currencies, while the planters' cost of production is ringgit-denominated. Given the steady world palm oil prices, upstream plantation earnings are expected to improve, and investor tend to spend more for capex in the long run.

\section{Conclusion}

Capital expenditure is a major driver of growth, not only for individual companies but also for overall economies. This paper investigates the determinant of capex for 40 palm oil companies in Malaysia that listed in Bursa Malaysia using a dynamic panel data analysis (GMM estimation). Overall, the empirical results provide a new evidence that the movement of world CPO prices plays a significant role in affecting the investment decision of palm oil-oriented companies in Malaysia. However, the domestic CPO prices is statistically not significant in influencing the investment decision of the palm oil-oriented firms. This signal that, the strength of world palm oil prices has given an advantage to the firm to allocate more spending in capex for their future performance. Another interesting finding are cash flow and sale growth are statistically significant in influencing the capex decision in the long run and short run, whereas average Q is only positive and significant in the long run but does not significant in short run.

The policy implications from this study suggest that in the long run, the industry players (in particular, palm oil-oriented firms) need to consider the movement of world CPO prices for their investment decision. Thus, by observing the world palm oil prices, the firm can properly plan for their investment in order to expand their business and also can generate more profit in future. In addition, the significant role of the cash flow on investment decision has indicated that firm need to manage efficiently their cash flow in order to ensure that they have enough cash for their future investment. Therefore, the plantation firms need to have good business model in generating more cash flow in future. For the policy makers, in particular to the Central Bank of Malaysia, they need to monitor the private sector cash flow in order to ensure that they have sufficient liquidity for operating their business (in particular, for investment activity). The monetary authority has also need to observe the credit market conditions and liquidity in the palm oil market in order to ensure that the domestic liquidity is reasonable to support the business agenda. Finally, since sales growth and Tobin-q are significant in influencing the capex in the long run, therefore proper strategy to improve the firm sales and firm equity price are necessary to generate more investment expanding in future. Thus, the firms need to diversify their sales strategy by penetrating a new market, and also need to care the movement of their stock prices.

\section{Acknowledgements}

The authors thankfully acknowledge financial support from the Universiti Kebangsaan Malaysia (UKM) research grant (Grant number: EP-2019-005).

\section{References}

Agung, J. (2000). Financial constraint, firms' investments and the channel of monetary policy in Indonesia. Applied Economics, 32(13), 1637-1646. 
Arellano, M., \& Bond, S. (1991). Some tests of specification for panel data: Monte Carlo evidence and an application to employment equations. Review of Economic Studies, 58(2), 277-297.

Arellano, M., \& Bover, O. (1995). Another look at the instrumental variable estimation of error components models. Joumal of Econometrics, 68(1), 29-51.

Bala, R., Darry, O., \& Matthew, C. H. Y. (2005). Firm size, ownership and performance in the Malaysian palm oil industry. Asian Academy of Management Journal of Accounting and Finance, 1(1), 81-104.

Baltagi, B. H. (2005). Econometric analysis of panel data (3rd ed.). West Sussex: John Wiley \& Sons.

Bhagat, S., Moyen, N., \& Suh, I. (2005). Investment and internal funds of distressed firms. Journal of Corporate Finance, 11(3), 449-472.

Blundell, R., \& Bond, S. (1998). Initial conditions and moment restrictions in dynamic panel data models. Journal of Econometrics, 87(1), 115-143.

Calderon, C. A., Chong, A., \& Loayza, N. V. (2002). Determinants of current account deficits in developing countries. Contribution to Macroeconomics, 2(1).

Fazzari, S. M., Hubbard, M. G., \& Petersen, B. C. (1988). Financing constraints and corporate investment. Brookings Papers on Economic Activity, 19(1), 141-206.

Gugler, K., Dennis, C. M., \& Yurtoglu, B. B. (2000). Marginal Q, Tobin's Q, cash flow and investment (University of Vienna Working Paper No. 0002).

Hausman, J. A., \& Taylor, W. E. (1981). Panel data and unobserved individual effects. Econometrica, 49(6), 1377-1398.

Ismail, M. A., Ibrahim, M. H., Yusoff, M., \& Zainal, M. P. (2010). Financial constraint and firm investment in Malaysia: An investigation of investment cash flow relationship. International Journal of Economic and Management, 4(1), 29-44.

Jelani, A. R., Hitam, A., Jamak, J., Noor, M., Gono, Y., \& Ariffin, O. (2008). Cantas TM -A tool for the efficient harvesting of oil palm fresh fruit bunches. Journal of Oil Palm Research, 20, $548-558$.

Joseph, P. O., \& Wu, S. (2000). Corporate investment: Propensities and constraints. UB SOM Summer Research grant.

Karim, Z. A. (2012). Monetary policy effects on investment spending: A firm-level study of Malaysia. Studies in Economic and Finance Journal, 29(4), 268-286.

Karim, Z. A., \& Azman-Saini, W. N. W. (2013). Firm-level investment and monetary policy in Malaysia: Do the interest rate and broad credit channels matter? Journal of Asia Pacific Economy, 18(3), 396-412.

Koo, J., \& Maeng, K. (2005). The effect of financial liberalization on firms' investments in Korea. Journal of Asian Economics, 16(2), 281-297.

Kopcke, R. W. (1993). The determinants of business investment: Has capital spending been surprisingly low? (New England Economic Review No. January).

Mat, A., \& Razak, R. C. (2011). Empirical research on the relationship between organizational learning capability and success of technological product innovation implementation in electrical and electronics sector. Australian Journal of Basic and Applied Sciences, 5(11), 730 738. 
Nickell, S. (1981). Biases in dynamic models with fixed effects. Econometrica, 49(6), 1417-1426.

Norhidayu, A., Nur Syazwani, M., Radzil, R., Amin, I., \& Balu, N. (2017). The production of crude palm oil in Malaysia. Journal of Economics and Management, 11(3), 591 - 606.

Nur Syazwani, M. N., Baba, M. D., \& Norani, N. (2014). Barriers of adopting harvesting technology in Malaysian oil palm industry. Australian Journal of Basic and Applied Sciences, 8(19), 198-200.

Pandey, I. M. (1989). Capital expenditure planning and control: A survey of Indian practice. MDU Management Journal, 2(1), 1-15.

Roodman, D. (2009). Practitioners' corner: A note on the theme of too many instruments. Oxford Bulletin of Economics and Statistic, 71(1), 135-158.

Sauaia, A. C. A. (2002). Is the Tobin's q a good indicator of a company's performance? Developments in Business Simulation and Experiential Learning, 29, 301-307.

Singhal, R., Fu, L., \& Parkash, M. (2016). Tobin's q ratio and firm performance. International Research Journal of Applied Finance, VII, 1-10. https://doi.org/10.0704/article-2

Subrahmanyam, V., Chhachhi, I., \& Brown, C. (2013). Determinants of capital expenditures across nations. Indian Journal of Economics \& Business, 12(1), 37-55. 